\title{
A simple and rapid DNA extraction method from leaves of grapevine suitable for polymerase chain reaction analysis
}

\author{
Sandra Lo Piccolo ${ }^{1}$, Antonio Alfonzo ${ }^{1}$, Gaetano Conigliaro ${ }^{1}$, Giancarlo Moschetti ${ }^{1}$, Santella \\ Burruano $^{1}$ and Amalia Barone ${ }^{2 *}$ \\ ${ }^{1}$ Dipartimento Demetra, Università di Palermo, Viale delle Scienze 4, 90128 Palermo, Italy. \\ ${ }^{2}$ Dipartimento di Scienze del Suolo, della Pianta, dell'Ambiente e delle Produzioni Animali, Università Federico II di \\ Napoli, Via Università 100, 80055 Portici, Italy.
}

Accepted 16 December, 2011

\begin{abstract}
The genomic grapevine (Vitis vinifera L.) DNA extraction is difficult because of secondary metabolites that interfere with DNA isolation procedures and subsequent applications. We developed a simple, rapid and efficient method for the extraction of genomic DNA from asymptomatic and pathogeninfected grape leaves. The protocol reported, based on a modified cetyl trimethylammonium bromide (CTAB) extraction procedure, allowed the rapid DNA extraction from little amounts of leaf material without employment of liquid nitrogen for initial tissue grinding. The protocol included polyvinylpyrrolidone (PVP) to bind phenolic compounds, $\beta$-mercaptoethanol to inhibit the oxidation of polyphenols, and a high concentration of $\mathrm{NaCl}(2.5 \mathrm{M})$ to increase the solubility of polysaccharides, thus reducing their co-precipitation with DNA. Final DNA solution did not contain polysaccharides, polyphenols and other major contaminants. The purity of genomic DNA was confirmed by $A_{260 / 280}$ and $A_{260 / 230}$ ratios calculated from the spectrophotometric readings. In addition, the quality of the DNA extracted from asymptomatic, Oidium tuckeri- and Plasmopara viticola-infected leaves of $V$. vinifera $L$. was evaluated in polymerase chain reaction (PCR) analyses by using different set of primers to be able to amplify vegetal, fungal and bacterial DNA.
\end{abstract}

Key words: Vitis vinifera L., DNA extraction, PCR, fungi, bacteria.

\section{INTRODUCTION}

Grapevine (Vitis vinifera L.), a member of the Ampelidaceae or Vitaceae family, is one of the oldest and most important perennial crops in the world. Recently, this plant has been used for gene mapping (Kikkert et al., 2005; Akkurt et al., 2007; Troggio et al., 2007), genetic transformation (Wang et al., 2005), and DNA fingerprinting (Adam-Blondon et al., 2004; Di Gaspero et al., 2007).

*Corresponding author. E-mail: amalia.barone@unina.it. Tel: +390812539491. Fax: +39 081-2539481.

Abbreviations: CTAB, Cetyl trimethylammonium bromide; EDTA, ethylenediaminetetraacetic acid; PCR, polymerase chain reaction; PVP, polyvinylpyrrolidone.
However, molecular markers require a fair amount of high purity DNA and it is often not easy to separate DNA from naturally occurring plant cell contaminants.

The genomic grapevine DNA extraction is difficult, especially when young leaves are unavailable. In fact, it is known that mature grapevine leaves contain high quantities of secondary metabolites, such as polysaccharides, polyphenols and tannins (Lodhi et al., 1994; Hanania et al., 2004). In addition, abiotic stress such as water and nutritional deficiencies or pathogen infection can significantly enhance the biosynthesis and accumulation of these secondary compounds (landolino et al., 2004). These contaminants have also been reported to cause difficulty in DNA purification in other plant species (Murray and Thompson, 1980; Katterman and Shattuck, 1983; Fang et al., 1992; Aljanabi et al., 1999). When plant 
cells are destroyed, these cytoplasmic contaminants come into contact with nuclei and other organelles, representing a major obstacle in DNA purification (Loomis, 1974; Fang et al., 1992; Aljanabi et al., 1999; Hanania et al., 2004). In particular, polyphenolic compounds can irreversibly bind proteins and nucleic acids to form highmolecular weight complexes (Porebski et al., 1997), whereas polysaccharides tend to co-precipitate with DNA (landolino et al., 2004) making the DNA viscous and unamplifiable in polymerase chain reaction (PCR). Therefore, these contaminants must be eliminated during DNA isolation. Although, several DNA extraction protocols have been described for plants containing high concentrations of secondary metabolites, the most of these require a large amount of plant tissue to be ground in liquid nitrogen (Busconi et al., 2003; Nazhad and Solouki 2008). In addition, liquid nitrogen is unavailable in many regions of the world. In this study, we describe a simple, rapid and efficient method to extract high quantities of quality genomic DNA from little amounts of asymptomatic grape leaves and grape leaves infected by some pathogens. The method involves a modified cetyl trimethylammonium bromide (CTAB) extraction procedure (Doyle and Doyle, 1990). Moreover, we demonstrate the usefulness of the extracted DNA for PCR-based techniques.

\section{MATERIALS AND METHODS}

\section{Plant material}

Thirty-six grapevine leaves, collected from plants cv. Insolia of two Sicilian vineyards located in Palermo $\left(38^{\circ} 06^{\prime} \mathrm{N}, 13^{\circ} 21^{\prime} \mathrm{E}\right.$; elevation $14 \mathrm{~m}$ ) and Trapani $\left(37^{\circ} 47^{\prime} \mathrm{N}, 12^{\circ} 34^{\prime} \mathrm{E}\right.$; elevation $\left.12 \mathrm{~m}\right)$, were used for genomic DNA extraction. Six plants for each vineyard, two asymptomatic, two infected by Oidium tuckeri and two infected by Plasmopara viticola, were sampled; three leaves for each plant were collected. All samples were frozen in dry ice at the time of survey and then stored at $-80^{\circ} \mathrm{C}$ until DNA extraction.

Moreover, three leaves of two certified pathogen-free plants, purchased from the nursery "Cuciti Vivai Trinacria Vitis", were also used for DNA extraction.

\section{Solutions}

Extraction buffer consisted of $2 \%$ CTAB, $100 \mathrm{mM}$ Tris- $\mathrm{HCl}(\mathrm{pH} 8.0)$, $25 \mathrm{mM}$ ethylenediaminetetraacetic acid (EDTA) ( $\mathrm{pH} 8.0), 2.5 \mathrm{M}$ $\mathrm{NaCl}, 2 \%$ polyvinylpyrrolidone (PVP), and $1 \% \beta$-mercaptoethanol. In addition, chlorophorm:isoamyl alcohol (24:1, v/v), isopropanol, $70 \%$ ethanol, TE buffer [10 mM Tris- $\mathrm{HCl}(\mathrm{pH} 8.0), 1 \mathrm{mM}$ EDTA ( $\mathrm{pH}$ $8.0)$ ], and RNase A (10 mg/ml) were prepared and stored.

\section{DNA extraction protocol}

The frozen leaves were taken out of the freezer and quickly ground to a fine powder with mortar and pestle (frozen rapidly at $-80^{\circ} \mathrm{C}$ ). Powders (200-300 mg) were immediately transferred to a $1.5 \mathrm{ml}$ microfuge tube containing $700 \mu \mathrm{l}$ of preheated $\left(60-65^{\circ} \mathrm{C}\right) \mathrm{CTAB}$ buffer. The tubes were shaken and incubated at $65^{\circ} \mathrm{C}$ for $60 \mathrm{~min}$ in a water bath, mixing by inversion 3-4 times during incubation.
Samples were centrifuged at $10000 \mathrm{rpm}$ for $10 \mathrm{~min}$ at $4^{\circ} \mathrm{C}$ and the aqueous phase was gently transferred into a new tube. Equal volume of chlorophorm:isoamyl alcohol (24:1) was added and mixed by inversion. Samples were centrifuged at $10000 \mathrm{rpm}$ for 10 $\min$ at $4^{\circ} \mathrm{C}$ and the aqueous phase was transferred into a new tube. Equal volume of isopropanol $\left(-20^{\circ} \mathrm{C}\right)$ was added to separate the DNA; samples were mixed and incubated at $-20^{\circ} \mathrm{C}$ for $30 \mathrm{~min}$. Precipitated DNA was centrifuged at $14000 \mathrm{rpm}$ for $10 \mathrm{~min}$ at $4^{\circ} \mathrm{C}$ and supernatant was discarded. DNA pellets were washed with 500 $\mu \mathrm{l}$ of $70 \%$ ethanol $\left(-20^{\circ} \mathrm{C}\right)$ and centrifuged at $14000 \mathrm{rpm}$ for $5 \mathrm{~min}$ at $4^{\circ} \mathrm{C}$. The resulting DNA pellets were air-dried at room temperature and dissolved in $200 \mu$ of TE buffer. RNase A was added to each sample $\left(1 / 100 \mu\right.$ DNA sample) and was incubated at $37^{\circ} \mathrm{C}$ for $1 \mathrm{~h}$. Samples were stored at $-20^{\circ} \mathrm{C}$.

\section{Quantity and purity of DNA}

Quantity and purity of the DNA extracted from all samples were checked by NanoDrop 1000 Spectrophotometer (Thermo Scientific). The absorbance ratios $A_{260} / A_{280}$ for protein contamination and $A_{260} / A_{230}$ for the presence of polyphenolic / polysaccharide compounds were used.

\section{PCR analysis}

In order to test the ability of amplification of extracted genomic DNA and to determine possible inhibitory materials which may interfere with the reactions, PCR analysis of DNA from all samples were carried out.

To analyze the quality of the plant DNA, grapevine cultivarspecific SCAR (sequence characterized amplified regions) primers OPF16Fw (5'-GGAGTACTGGTTCACTAG-3') and OPF16Rv (5'GGAGTACTGGCCTTACTC-3') (Vidal et al., 2000) were used. The amplification reaction was performed in a total reaction volume of $25 \mu \mathrm{l}$ containing $50 \mathrm{ng}$ of DNA template, $100 \mu \mathrm{M}$ of dNTPs, $0.2 \mu \mathrm{M}$ of each primer, $0.5 \mathrm{U}$ of Taq DNA Polymerase (GoTaq, Promega, USA) and $1 \mathrm{X}$ GoTaq buffer (1.5 $\mathrm{mM} \mathrm{MgCl}_{2}$, Promega). A negative control (PCR mixture without DNA) was included in all PCR experiments. The amplification reaction was carried out in a Thermocycler T1 (Biometra) as follows: initial denaturation at $94^{\circ} \mathrm{C}$ for $2 \mathrm{~min}, 45$ cycles of denaturation at $94^{\circ} \mathrm{C}$ for $1 \mathrm{~min}$, annealing at $50^{\circ} \mathrm{C}$ for $1 \mathrm{~min}$, extension at $72^{\circ} \mathrm{C}$ for $2 \mathrm{~min}$ and final extension at $72^{\circ} \mathrm{C}$ for $7 \mathrm{~min}$.

To amplify the internal transcribed spacer regions (ITS1-5.8SITS2) of rRNA gene from fungi, primers ITS1F (fungus specific: 5'CTTGGTCATTTAGAGGAAGTAA-3') (Gardes and Bruns, 1993) and ITS4 (universal: 5'-TCCTCCGCTTATTGATATGC-3') (White et al., 1990) were used. The reaction volume $(40 \mu \mathrm{l})$ contained $50-100$ ng of DNA template, $2 \mathrm{mM}$ of $\mathrm{MgCl}_{2}, 0.2 \mathrm{mM}$ of dNTP, $0.3 \mu \mathrm{M}$ of each primer, $0.5 \mathrm{U}$ of Taq DNA Polymerase (Dream Taq, Fermentas, Italy) and 1X Dream Taq buffer (Fermentas). As positive control Acremonium byssoides strain A21, endophyte in asymptomatic grape leaves (Burruano et al., 2008), was used. The amplification program consisted of one initial denaturation at $95^{\circ} \mathrm{C}$ for $2 \mathrm{~min}$, followed by 35 cycles of $95^{\circ} \mathrm{C}$ for $30 \mathrm{~s}, 55^{\circ} \mathrm{C}$ for $20 \mathrm{~s}$, $72^{\circ} \mathrm{C}$ for $1 \mathrm{~min}$ and a final extension at $72^{\circ} \mathrm{C}$ for $5 \mathrm{~min}$.

To amplify the 16S rRNA gene from bacteria, universal primers fD1 (5'-AGAGTTTGATCCTGGCTCAG-3') and rD1 (5'AAGGAGGTGATCCAGCC-3') (Weisburg et al., 1991) were used. The $50 \mu \mathrm{l}$ PCR mixture contained 50-100 ng of DNA template, 2.5 $\mathrm{mM}$ of $\mathrm{MgCl}_{2}, 0.25 \mathrm{mM}$ of dNTPs, $0.2 \mu \mathrm{M}$ of each primer, $2.5 \mathrm{U}$ of Taq DNA Polymerase (Dream Taq, Fermentas) and 1X Dream Taq buffer (Fermentas). As positive control Bacillus subtilis strain AG1, isolated from grape wood infected by "esca" syndrome (Alfonzo et al., 2009), was used. The PCR was performed under the following conditions: $95^{\circ} \mathrm{C}$ for $3 \mathrm{~min} ; 30$ cycles of $94^{\circ} \mathrm{C}$ for $1 \mathrm{~min}, 54^{\circ} \mathrm{C}$ for 45 
Table 1. Evaluation of extracted DNA according to spectral absorbance ratios (A260/280 and A260/230) and final concentration $(\mathrm{ng} / \mu \mathrm{l})$.

\begin{tabular}{lccc}
\hline Sample leaf & $\mathbf{A}_{\mathbf{2 6 0 / A 2 8 0}}$ & $\mathbf{A}_{\mathbf{2 6 0 / A 2 3 0}}$ & $\mathbf{C c}(\mathbf{n g} / \boldsymbol{\mu l})$ \\
\hline Asymptomatic & $1.89 \pm 0.02$ & $2.18 \pm 0.01$ & $270.0 \pm 22.2$ \\
Oidium tuckeri-infected & $1.82 \pm 0.02$ & $2.08 \pm 0.02$ & $246.8 \pm 20.3$ \\
Plasmopara viticola-infected & $1.80 \pm 0.01$ & $2.02 \pm 0.01$ & $205.2 \pm 18.2$ \\
Certified pathogen-free & $1.87 \pm 0.01$ & $2.15 \pm 0.01$ & $263.0 \pm 19.8$ \\
\hline
\end{tabular}

Values are mean \pm SE (standard error).

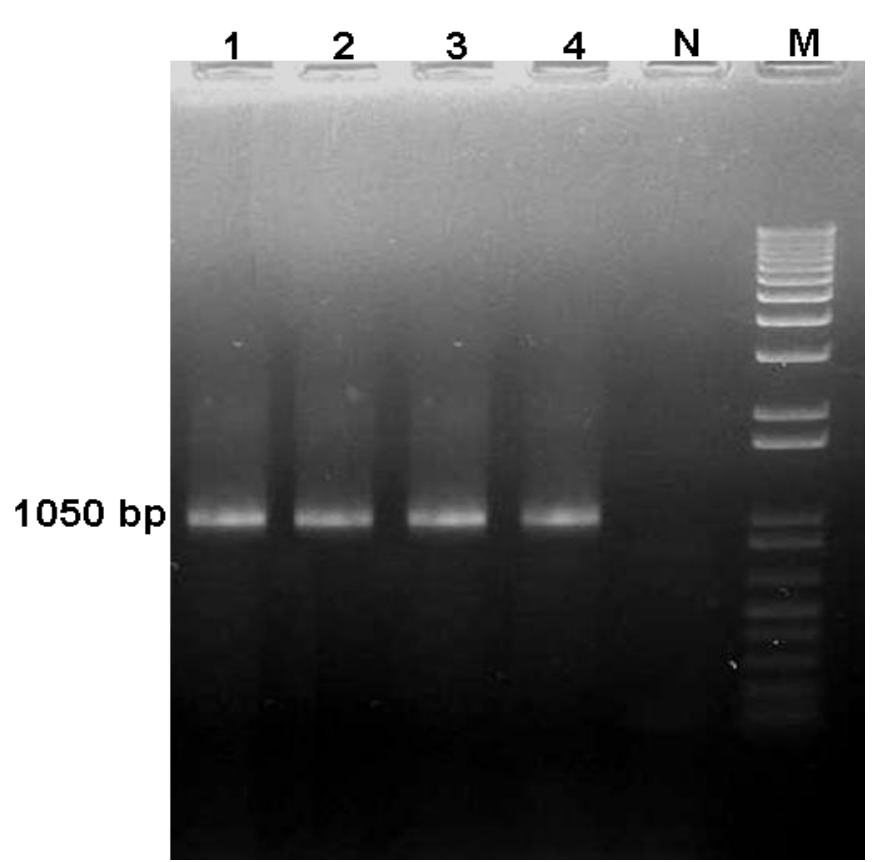

Figure 1. PCR products obtained using the primers OPF16Fw and OPF16Rv from asymptomatic leaf (Lane 1), Oidium tuckeri-infected leaf (Lane 2), Plasmopara viticola-infected leaf (Lane 3) and freepathogen leaf (Lane 4). N: Negative control without DNA. M: Molecular marker (1 Kb plus DNA ladder, Invitrogen, USA).

$\mathrm{s}, 72^{\circ} \mathrm{C}$ for $2 \mathrm{~min} ; 72^{\circ} \mathrm{C}$ for $7 \mathrm{~min}$. Five microliters of all PCR products were analyzed by electrophoresis in a $1.5 \%$ agarose gel stained with SYBR Green I nucleic acid stain and visualized under UV light.

\section{RESULTS AND DISCUSSION}

Grapevine contains high concentrations of polysaccharides, polyphenols, tannins and other secondary metabolites (Lodhi et al., 1994; Hanania et al., 2004). These compounds may hamper the DNA isolation processes and subsequent analysis such as DNA restriction, amplification, cloning, genomic DNA blot hybridization, and genomic DNA library construction (Pandey et al., 1996; Khanuja et al., 1999; Li et al., 2007; Barzegari et al., 2010). Therefore, these contaminants must be eliminated during DNA isolation.
The modified extraction method (Doyle and Doyle, 1990) reported in this study proved to be effective. We have obtained, in a few hours, high yields of DNA from little amounts of grapevine leaf tissues $(0.2$ to $0.3 \mathrm{~g})$, avoiding the tedious grinding of each specimen in liquid nitrogen, unlike the standard method that started from 0.5 to $1 \mathrm{~g}$ of leaf material and involved the use of liquid nitrogen. This method does not require lyophilization of sample and expensive laboratory material. In agreement with previous reports (Fang et al., 1992; Lodhi et al., 1994), PVP and $\beta$-mercaptoethanol were absolutely necessary to remove polyphenols from mature and damaged leaf tissues. Moreover, the use of a higher molar concentration $(2.5 \mathrm{M})$ of $\mathrm{NaCl}$, compared to the original protocol $(1.4 \mathrm{M})$, enabled elimination of the polysaccharides. It should be emphasized that the amount of leaf tissue used for DNA extraction should not exceed $300 \mathrm{mg}$ per sample. Otherwise, it is difficult to effectively remove contaminants even when PVP, $\beta$-mercaptoethanol and $\mathrm{NaCl}$ are used in later steps.

The spectrophotometer analysis for $A_{260} / A_{280}$ and $\mathrm{A}_{260} / \mathrm{A}_{230}$ resulted in 1.80 to 1.89 and $>2$ on average, respectively indicating that the extracted DNA was free from proteins and polyphenolic/polysaccharide compounds (Table 1). The average final concentration of DNA ranged from 205 to $270 \mathrm{ng} / \mu \mathrm{l}$ (Table 1).

The purity and the quality of the extracted DNA were confirmed by PCR analysis. In fact, amplifiable DNA was obtained from all tested leaves. In particular, using grapevine cultivar-specific SCAR primers, a fragment of $1050 \mathrm{bp}$ was amplified (Figure 1). All the samples also exhibited successful amplification of ITS regions of rRNA gene from fungi and 16S rRNA gene from bacteria, as demonstrated by clear bands of $\sim 600$ bp (Figure 2) and $\sim 1600$ bp (Figure 3) obtained, respectively. The detection of fungal DNA also in leaves from certified pathogen-free plants and in asymptomatic leaves is probably due to the presence of fungal endophytes, as reported in $V$. vinifera by Mostert et al. (2000) and Burruano et al. (2008). Moreover, endophytic bacteria in grapevine leaf tissues have also been reported by Bulgari et al. (2009) and Lo Piccolo et al. (2010); this explains the presence of bacterial DNA in all sampled leaves. Furthermore, the DNA could be used for denaturing gradient gel electrophoresis (DGGE) analysis to study different bacterial and fungal compositions between asymptomatic and 


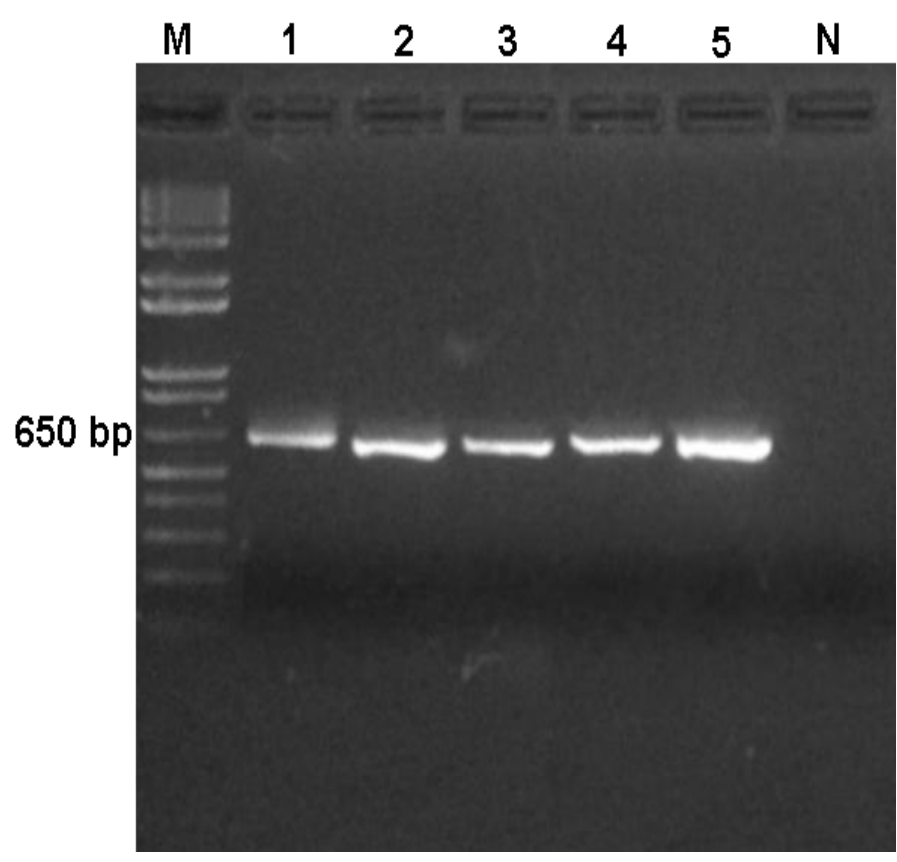

Figure 2. Amplification of ITS regions of rRNA gene from asymptomatic grapevine leaf (Lane 1), O. tuckeri-infected leaf (Lane 2), P. viticola-infected leaf (Lane 3), free-pathogen leaf (Lane 4) and Acremonium byssoides strain A21 (Lane 5). N: Negative control without DNA. M: Molecular marker (1 Kb plus DNA ladder, Invitrogen).

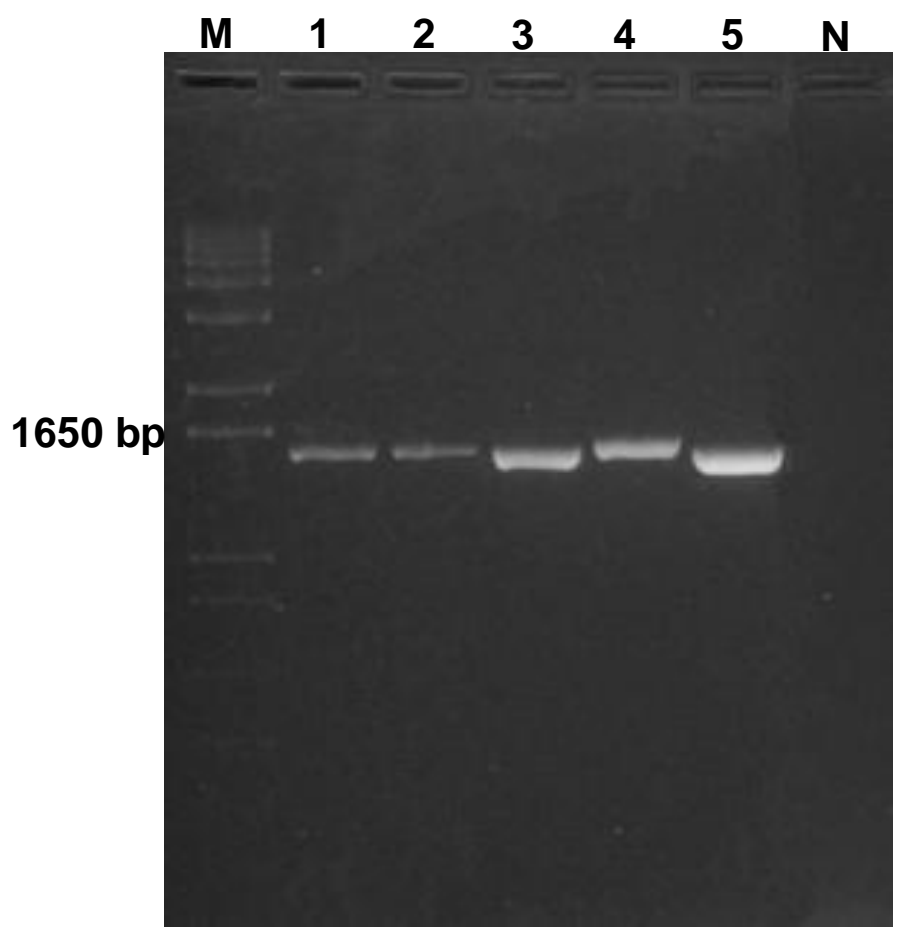

Figure 3. Amplification of 16S rRNA gene from asymptomatic grapevine leaf (Lane 1), O. tuckeri-infected leaf (Lane 2), $P$. viticolainfected leaf (Lane 3), free-pathogen leaf (Lane 4) and Bacillus subtilis strain AG1 (Lane 5). N: Negative control without DNA. M: Molecular marker (1 Kb plus DNA ladder, Invitrogen). symptomatic grape leaves.

\section{Conclusion}

The protocol reported in this study, that includes the use of PVP, $\beta$-mercaptoethanol and a high concentration of $\mathrm{NaCl}(2.5 \mathrm{M})$, without the tedious employment of liquid nitrogen allows the rapid and simple isolation of quality genomic DNA from little amounts of leaf tissues of $V$. vinifera $L$., suitable for PCR amplification and subsequent molecular analysis.

\section{ACKNOWLEDGMENT}

The authors thank Dr. Marcella Molisso for her help in amplification reaction of plant DNA.

\section{REFERENCES}

Adam-Blondon AF, Roux C, Claux D, Butterlin G, Merdinoglu D, This P (2004). Mapping 245 SSR markers on the Vitis vinifera genome: a tool for grape genetics. Theor. Appl. Genet. 109: 1017-1027.

Akkurt M, Welter L, Maul E, Topfer L, Zyprian E (2007). Development of SCAR markers linked to powdery mildew (Uncinula necator) resistance in grapevine (Vitis vinifera L. and Vitis sp.). Mol. Breed. 19: 103-111.

Alfonzo A, Conigliaro G, Torta L, Burruano S, Moschetti G (2009). Antagonism of Bacillus subtilis strani AG1 against vine wood fungal pathogens. Phytopathol. Mediterr. 48: 155-158.

Aljanabi SM, Forget L, Dookun A (1999). An improved and rapid protocol for the isolation of polysaccharide and polyphenol free sugarcane DNA. Plant Mol. Biol. Rep. 17: 1-8.

Barzegari A, Vahed SZ, Atashpaz S, Khani S, Omidi Y (2010). Rapid and simple methodology for isolation of high quality genomic DNA from coniferous tissues (Taxus baccata). Mol. Biol. Rep. 37: 833-837.

Bulgari D, Casati P, Brusetti L, Quaglino F, Brasca M, Daffonchio D, Bianco PA (2009). Endophytic bacterial diversity in grapevine (Vitis vinifera L.) leaves described by $16 \mathrm{~S}$ rRNA gene sequence analysis and length heterogeneity-PCR. J. Microbiol. 47: 393-401.

Burruano S, Alfonzo A, Lo Piccolo S, Conigliaro G, Mondello V, Torta L, Moretti M, Assante G (2008). Interaction between Acremonium byssoides and Plasmopara viticola in Vitis vinifera. Phytopathol. Mediterr. 47: 122-131.

Busconi M, Foroni C, Corradi M, Bongiorni C, Cattapan F, Fogher C (2003). DNA extraction from olive oil and its use in the identification of the production cultivar. Food Chem. 83: 127-134.

Di Gaspero G, Cipriani G, Adam-Blondon AF, Testolin R (2007). Linkage maps of grapevine displaying the chromosomal locations of 420 microsatellite markers and 82 markers for R-gene candidates. Theor. Appl. Genet. 114: 1249-1263.

Doyle JJ, Doyle JL (1990). Isolation of plant DNA from fresh tissue. Focus, 12: 13-15.

Fang G, Hammer S, Grumet R (1992). A quick and inexpensive method for removing polysaccharides from plant genomic DNA. Biotechniques, 13: 52-54.

Gardes M, Bruns TD (1993). ITS primers with enhanced specificity for basidiomycetes - application to the identificationof mycorrhizae and rusts. Mol. Ecol. 2: 113-118.

Hanania U, Velcheva M, Sahar N, Perl A (2004). An Improved Method for Isolating High-Quality DNA From Vitis vinifera Nuclei. Plant Mol. Biol. Rep. 22: 173-177.

landolino AB, Goes da Silva F, Lim H, Choi H, Williams LE, Cook DR (2004). High-Quality RNA, cDNA, and Derived EST Libraries from Grapevine (Vitis vinifera L.). Plant Mol. Biol. Rep. 22: 269-278. 
Katterman FRH, Shattuck VL (1983). An effective method of DNA isolation from the mature leaves of Gossypium species that contain large amounts of phenolic terpenoids and tannins. Prep. Biochem. 13: 347-359.

Khanuja SPS, Shasany AK, Darokar MP, Kumar S (1999). Rapid isolation of DNA from dry and fresh samples of plants producing large amounts of secondary metabolites and essential oils. Plant Mol. Biol. Rep. 17: 1-7.

Kikkert JR, Striem MJ, Vidal JR, Wallace PG, Barnard J, Reisch BI (2005). Long-term study of somatic embryogenesis from anthers and ovaries of 12 grapevine (Vitis sp.) genotypes. In Vitro Cell. Dev. Biol. Plant, 41:232-239.

Li JT, Yang J, Chen DC, Zhang XL, Tang ZS (2007). An optimized minipreparation method to obtain high-quality genomic DNA from mature leaves of sunflower. Genet. Mol. Res. 6(4): 1064-1071.

Lodhi MA, Ye GN, Weeden NF, Reisch BI (1994). A simple and efficient method for DNA extraction from grapevine cultivars and Vitis species. Plant Mol. Biol. Rep. 12: 6-13.

Loomis WD (1974). Overcoming problems of phenolic and quinines in the isolation of plant enzymes and organelles. Method. Enzymol. 31: 528-544.

Lo Piccolo S, Ferraro V, Alfonzo A, Settanni L, Ercolini D, Burruano S, Moschetti $G$ (2010). Presence of endophytic bacteria in Vitis vinifera leaves as detected by fluorescence in situ hybridization. Ann. Microbiol. 60: 161-167.

Mostert L, Crows PW, Petrini O (2000). Endophytic fungi associated with shoots and leaves of Vitis vinifera, with specific reference to the Phomopsis viticola complex. Sydowia, 52: 46-58.

Murray MG, Thompson WF (1980). Rapid isolation of high molecular weight plant DNA. Nucleic Acids Res. 8: 4321-4325

Nazhad NR, Solouki M (2008). Separation of DNA for molecular markers analysis from leaves of the Vitis vinifera. Pak. J. Biol. Sci. 11: 1436-1442.

Pandey R, Adams R, Flournoy L (1996). Inhibition of random amplified polymorphic DNAs (RAPDs) by plant polysaccharides. Plant Mol. Biol. Rep. 14: 17-22.

Porebski S, Bailey LG, Baum BR (1997). Modification of a CTAB DNA extraction protocol for plants containing high polysaccharide and polyphenol components. Plant Mol. Biol. Rep. 15: 8-15.
Troggio M, Malacarne G, Coppola G, Segala C, Cartwright DA, Pindo M, Stefanini M, Mank R, Moroldo M, Morgante M, Grando MS, Velasco R (2007). A dense single-nucleotide polymorphism-based genetic linkage map of grapevine (Vitis vinifera L.) anchoring pinot noir bacterial artificial chromosome contigs. Genetics, 176: 26372650.

Vidal JR, Delavault P, Coarer M, Defontaine A (2000). Design of grapevine (Vitis vinifera L.) cultivar-specific SCAR primers for PCR fingerprinting. Theor. Appl. Genet. 101: 1194-1201.

Wang Q, Li P, Hanania U, Sahar N, Mawassi M, Gafny R, Sela I, Tanne E, Perl A (2005). Improvement of Agrobacterium-mediated transformation efficiency and transgenic plant regeneration of Vitis vinifera L. by optimizing selection regimes and utilizing cryopreserved cell suspensions. Plant Sci. 168: 565-571.

Weisburg WG, Barns SM, Pelletier DA, Lane DJ (1991). 16S ribosomal DNA amplification for phylogenetic study. J. Bacteriol. 173: 697-703.

White TJ, Bruns TD, Lee SB, Taylor JW (1990). Amplification and direct sequencing of fungal ribosomal RNA genes for phylogenetics. In: Innis MA, Gelfand DH, Sninsky JJ, White TJ (Eds) PCR protocols: a guide to methods and applications. Academic Press San Diego. pp. 315-321. 